\title{
ORAL HEALTH RELATED QUALITY OF LIFE: PERSPECTIVES
}

\author{
Poonam Sood ${ }^{1}$, Gourav Ahuja ${ }^{2}$ Diljot Kaur Makkar ${ }^{3}$, Rohini Gaba ${ }^{4}$, Jasmohan Singh Sidana \\ ${ }^{1}$ Sr. Lecturer, Department of Public Health Dentistry, BRS Dental College and General Hospital, Haryana, India \\ ${ }^{2}$ Sr. Lecturer, Department of Oral and Maxillofacial Surgery, BRS Dental College and General Hospital, Haryana, India \\ ${ }^{3}$ Sr. Lecturer, Department of Public Health Dentistry, Surendera Dental College and Research Institute, Rajasthan, India \\ ${ }^{4}$ Sr. Lecturer, Department of Periodontics, Maharaja Ganga Singh Dental College and Research Institute, Rajasthan, India \\ ${ }^{5}$ Sr. Lecturer, Department of Oral Medicine and Radiology, Jaipur Dental College, Rajasthan, India
}

\begin{abstract}
Good oral health is essential for the overall well being of an individual. Oral diseases like dental caries, periodontal diseases and oral cancer are highly prevalent and can lead to pain, discomfort, anxiety, poor facial appearance, low self esteem and impaired function. With patient centric measures gaining importance, it is essential to incorporate patient centric measures while restoring the oral health. OHRQoL aims to add this wider view to the clinical assessment of an individual's oral health. It challenges biomedical model of health and provides complete view of the health and disease status of an individual. It is an individual's assessment of how functional, psychological, social and other factors affect personal well being. Various generic and oral health specific quality of life instruments have been developed to assess oral health related quality of life. It has implications in routine clinical practice, research, patient education, surveys and policy formulations. The overall result is a satisfied individual, clinician, researcher and community.
\end{abstract}

Keywords: Oral Health, Quality of Life, Oral Health Related Quality of Life.

\section{INTRODUCTION}

Quality of life is a recent and growing area of interest. ${ }^{1,23}$ The fact that more than thousand research articles are indexed each year under this heading highlights its growing sphere of influence. ${ }^{4}$ It is a multidimensional concept that captures people's perceptions about factors that are important in their everyday lives. It is defined as an individual's perception of his or her position in life, in the context of the culture and value systems in which they live and in relation to their goals, expectations and concerns (WHO 1993). ${ }^{5}$

Health is one of the important determinants of quality of life. It is a resource and not simply absence of disease. It is multidimensional in nature and addresses physical, mental, social, psychological, environmental, and economical aspects of an individuals' life (WHO 1948). ${ }^{6}$ Hence one needs to capture all these to determine where an individual stands in the matters of health and what can be done to enhance it further. Also advancements in science and technology, improvement in environment and health care facilities has added years to the life. Today, what matters most is the quality healthy years spend in this enhanced life span. The time tested traditional (biomedical) model is limited in approach and fails to address all the dimensions. ${ }^{7}$ New approaches to assess the health of a patient are needed to extend this biomedical model.

Health related quality of life is one of such approaches. It addresses the tradeoff between how long and how well people live. It is the value assigned by an individual to the impairments, functional states, perceptions and social opportunities, which in turn are influenced by disease, injury, treatment and policy. ${ }^{5}$ With the surge of patient centric approaches and more autonomy assigned to the patients, health care professionals also agree that recording and understanding patient's perceptions is important in decision making process to provide a comprehensive evaluation and effectiveness of health measures. ${ }^{8,9}$

Oral cavity is an integral part of the overall wellbeing of an individual and is 
often considered as mirror of the general health. Poor oral health can impair the overall health. Also many systemic diseases produce oral manifestations which can further affect the life of an individual. Oral diseases like dental caries, periodontal diseases and oral cancer are highly prevalent and can significantly impair the quality of life in large number of individuals leading to pain, discomfort, anxiety, poor facial appearance, low self esteem and impaired function. ${ }^{8,910}$ In studies which assessed the association between objective measures of dental disease (such as presence of dental caries or periodontal attachment loss) and patient based longer merely be seen as the absence of caries or periodontal disease; a patient's mental and social well being should be considered as well. The concept of "Oral Health Related Quality of Life" aims to capture this new perspective. It is recognized by the WHO as an important segment of the Global Oral Health Program (WHO, 2003). ${ }^{14}$ Oral healthcare researchers and policymakers have recognized that assessment of oral health outcomes is vital in planning oral healthcare programmes. ${ }^{9}$

Hence, the aim of this review is to introduce concepts of oral health related quality of life, instruments

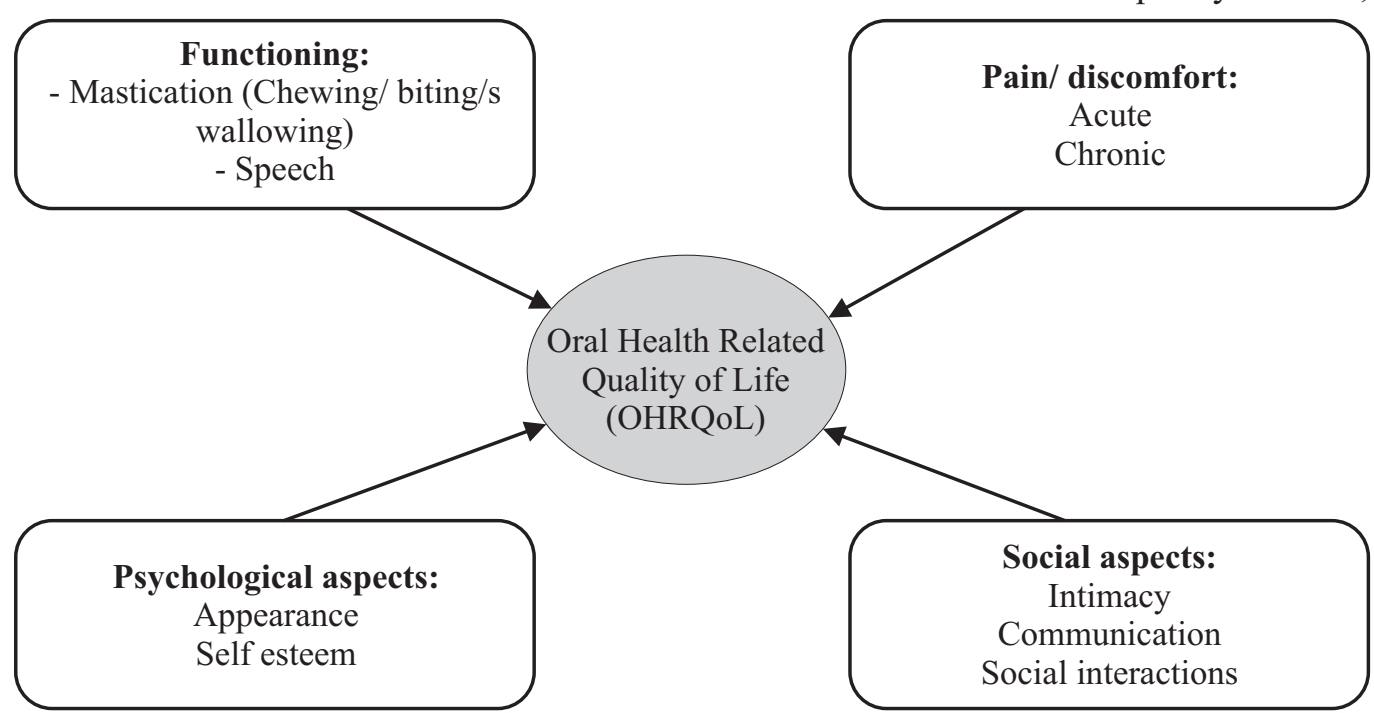

Figure 1: Factors determining OHRQoL

opinions of oral status, the relationship was weak and objective measures did not accurately reflect patients' perceptions. ${ }^{11,12}$

Hence, appropriate measures of oral health assessment should go beyond the simple use of a normative measure and achieve the necessary balance between clinical assessments and subjective perceptions, while considering factors that are important for the outcome of treatment. Systemic review by Mariko Naito et al showed that there is significant association between oral health status and health related quality of life. ${ }^{13}$ Oral cancer and temporomandibular joint disorders have been shown to significantly impair health related quality of life. ${ }^{14}$ For the field of dentistry, this new perspective on health suggested that the ultimate goal of dental care, namely good oral health, should no available to record it and to facilitate comparisons.

Definition (Figure 1)

Oral Health Related Quality of Life (OHRQoL) is defined as a person's assessment of how the following types of factors affect his or her wellbeing ${ }^{10}$ :

1. Functional factors

2. Psychological factors (concerning the person's appearance and self- esteem)

3. Social factors (such as interaction with others)

4. The experience of pain/discomfort

These four set of factors are inturn influenced by the person $(\mathrm{P})$ experiencing these, the situation $(\mathrm{S})$ under which he/she experiences and the interaction between the two.

Individual attitudes are not constant, they vary with 
time and experience, and are modified by phenomena such as coping, expectancy and adaptation. For example, an individual who had eating problems due to pain and discomfort, would have rated this problem as extremely important at one point in time. However, when this problem is diagnosed as oral cancer, and treated with radiotherapy and/or surgery, the same individual may report the original problem as relatively unimportant.

Similarly a person's background and cultural upbringing; current and past experiences with oral diseases or health care; current status of mind such as depression or happiness; as well as hopes for the future will determine their response to the situations.

\section{OHRQoL Instruments/ measures/ scales}

The need for a comprehensive approach to study the social and psychological impact of oral diseases lead to the development of a number of generic and oral health related instruments/ measures. The need for such instruments was expressed by Cohen and Jago, who indicated the lack of data relating to psycho-social impact of oral health problems at that time. ${ }^{9}$ In response to this, workers such as Reisine, developed societal indicators such as work loss due to dental problems to describe the social impact of oral disease. ${ }^{15,16}$ Further approaches focused on evaluation of patient's perceptions of salience of events, as demonstrated by the Dental Impact Profile. A final approach focused to place functional disorders and their social consequences in a hierarchy of outcomes. ${ }^{17}$

Overall, the instruments can be classified into two types $^{9,10}$ :

Generic instruments: These measure the effect of any condition say, oral conditions on the overall health of a person. These instruments contain a broad measure of health status encapsulated in one measure. The psychometric properties of these measures are known, and comparisons can be made between populations with different problems using these scales. However, there is concern that generic health status measures are not sensitive to oral health outcomes and that discriminant validity and responsiveness to change properties of these measures may be poor. These include instruments like (Table 1):

1. SF-36 (Short Form-36) ${ }^{18}$

2. EuroQol- 5D (European Quality of Life- 5 Dimensions) $)^{19,20}$

Specific instruments: These disease specific instruments are entirely designed to address the oral health conditions like dental caries, periodontal diseases, oral cancer, malocclusion etc. These offer the brevity and the ability to focus on the unique aspects of the disease being studied. They are more likely to detect subtle changes in specific conditions, thus having better responsiveness. However comparison across diseases is not possible. These include instruments like (Table 1):

1. Sociodental scale (Cushing 1986) ${ }^{21}$

2. RAND Dental Index (Dolan 1991) $)^{22}$

3. General Oral Health Assessment Index (GOHAI) (Atchison 1990) $^{23}$

4. Dental Impact Profile (DIP) (Strauss 1993) ${ }^{24}$

5. Oral Health Impact Profile (OHIP) (Slade 1994)

6. Subjective Oral Health Status Indicators (SOHSI) $($ Locker 1994)

7. Oral Health Quality of Life Inventory (OHQLI) $\left(\right.$ Cornell 1997) ${ }^{27}$

8. Dental Impact on Daily Living (DIDL) (Leao $1996)^{28}$

9. Oral Health- Related Quality of Life (OHRQoL) $\left(\right.$ Kressin 1996) ${ }^{29}$

10. Oral Impacts on Daily Performances (OIDP) (Adulyanon 1996) $^{30}$

No single instrument can be regarded as a standard, comprehensive instrument for measurement of OHRQoL. A further approach suggested by Bowling is to use both an appropriate disease specific measure and a generic measure. ${ }^{31}$ The rationale is to have a generic measure with core quality of life statements, and disease specific statements to improve responsiveness. The choice of the instruments used however, depends on the purpose of the study, needs and requirements of the researcher, clinician and the participant, availability, efficiency and completeness of instrument and the outcome to be measured.

\section{Implications}

OHRQoL has implications on clinical practice, basic and applied research and oral health education (Figure 2). ${ }^{10}$

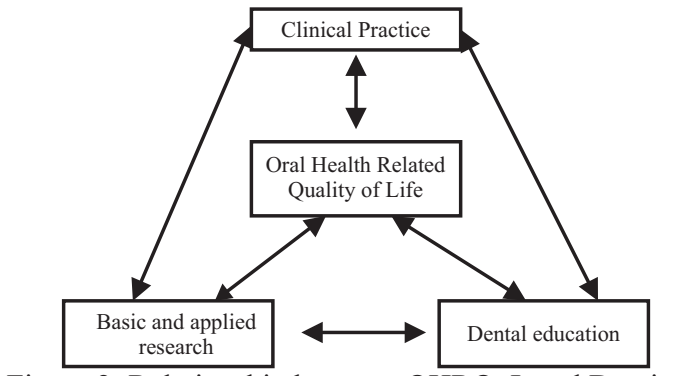

Figure 2: Relationship between OHRQoL and Dentistry 
Table 1: Oral Health Related Quality of Life Questionnaires

\begin{tabular}{|c|c|c|c|c|}
\hline Measure & Dimension measured & $\begin{array}{c}\text { No. of } \\
\text { questions }\end{array}$ & Example of question & Response format \\
\hline SF- $36^{18}$ & $\begin{array}{l}\text { Physical function, role } \\
\text { physical, bodily pain, } \\
\text { general health, mental } \\
\text { health, role emotional, } \\
\text { social function, vitality }\end{array}$ & 36 & $\begin{array}{l}\text { In the past one week how your } \\
\text { health has been limited by } \\
\text { pain? }\end{array}$ & $\begin{array}{l}5 \text { categories: "much } \\
\text { better to much } \\
\text { worse" }\end{array}$ \\
\hline EuroQol- 5D ${ }^{19,20}$ & $\begin{array}{l}\text { Mobility, self care, usual } \\
\text { activities, pain, anxiety/ } \\
\text { depression }\end{array}$ & 5 & Mobility? & $\begin{array}{l}3 \text { categories: "no } \\
\text { problem, some } \\
\text { problem, unable to } \\
\text { do work" }\end{array}$ \\
\hline $\begin{array}{l}\text { Sociodental Scale } \\
(\mathrm{SIS})^{21}\end{array}$ & $\begin{array}{l}\text { Chewing, talking, } \\
\text { smiling, laughing, pain, } \\
\text { appearance }\end{array}$ & 14 & $\begin{array}{l}\text { Are there any types of foods } \\
\text { you have difficulties chewing? }\end{array}$ & Yes/no \\
\hline $\begin{array}{l}\text { RAND Dental } \\
\text { Health Index }\end{array}$ & $\begin{array}{l}\text { Pain, worry, } \\
\text { conversation }\end{array}$ & 3 & $\begin{array}{l}\text { How much of the pain have } \\
\text { your gums and teeth caused } \\
\text { you? }\end{array}$ & $\begin{array}{l}4 \text { categories: "not at } \\
\text { all" to a "great deal" }\end{array}$ \\
\hline $\begin{array}{l}\text { General Oral } \\
\text { Health } \\
\text { Assessment } \\
\text { Index } \\
(\text { GOHAI })^{23}\end{array}$ & $\begin{array}{l}\text { Chewing, eating, social } \\
\text { contacts, appearance, } \\
\text { pain, worry, self - } \\
\text { consciousness }\end{array}$ & 12 & $\begin{array}{l}\text { How often did you limit the } \\
\text { kinds or amounts of food you } \\
\text { eat because of the problems } \\
\text { with your teeth or dentures? }\end{array}$ & $\begin{array}{l}6 \text { categories: } \\
\text { "always" to "never" }\end{array}$ \\
\hline $\begin{array}{l}\text { Dental Impact } \\
\text { Profile } \\
(\text { DIP })^{24}\end{array}$ & $\begin{array}{l}\text { Appearance, eating, } \\
\text { speech, confidence, } \\
\text { happiness, social life, } \\
\text { relationships }\end{array}$ & 25 & $\begin{array}{l}\text { Do you think your teeth or } \\
\text { dentures have a good effect } \\
\text { (positive), a bad effect } \\
\text { (negative), or no effect on your } \\
\text { feeling comfortable? }\end{array}$ & $\begin{array}{l}3 \text { categories: "good } \\
\text { effect, bad effect, no } \\
\text { effect" }\end{array}$ \\
\hline $\begin{array}{l}\text { Oral Health } \\
\text { Impact Profile } \\
(\mathrm{OHIP})^{25}\end{array}$ & $\begin{array}{l}\text { Function, pain, physical } \\
\text { disability, psychological } \\
\text { disability, social } \\
\text { disability, handicap }\end{array}$ & 49 & $\begin{array}{l}\text { Have you had difficulty } \\
\text { chewing foods because of } \\
\text { problems with your teeth, } \\
\text { mouth or dentures? }\end{array}$ & $\begin{array}{l}5 \text { categories: "very } \\
\text { often" to "never" }\end{array}$ \\
\hline $\begin{array}{l}\text { Subjective Oral } \\
\text { Health Status } \\
\text { Indicators } \\
\text { (SOHSI) }^{26}\end{array}$ & $\begin{array}{l}\text { Chewing, speaking, } \\
\text { symptoms, eating, } \\
\text { communication, social } \\
\text { relations }\end{array}$ & 42 & $\begin{array}{l}\text { During the last year, how often } \\
\text { have dental problems caused } \\
\text { you to have difficulty } \\
\text { sleeping? }\end{array}$ & $\begin{array}{l}\text { Various, depending } \\
\text { on question format }\end{array}$ \\
\hline $\begin{array}{l}\text { Oral Health } \\
\text { Quality of Life } \\
\text { Inventory } \\
(\text { OHQoLI })^{27}\end{array}$ & $\begin{array}{l}\text { Oral health, nutrition, } \\
\text { self- related oral health, } \\
\text { overall quality of life }\end{array}$ & 56 & $\begin{array}{l}\text { Two part questions: (A) How } \\
\text { important it is for you to speak } \\
\text { clearly? } \\
\text { (B) How happy are you with } \\
\text { your ability to speak clearly? }\end{array}$ & $\begin{array}{l}\text { Part A: } 4 \text { categories } \\
\text { (not at all important } \\
\text { to very important) } \\
\text { Part B: } 4 \text { categories } \\
\text { (unhappy to happy) }\end{array}$ \\
\hline $\begin{array}{l}\text { Dental Impact on } \\
\text { Daily Living } \\
\text { (DIDL) }^{28}\end{array}$ & $\begin{array}{l}\text { Comfort, appearance, } \\
\text { pain, daily activities, } \\
\text { eating }\end{array}$ & 36 & $\begin{array}{l}\text { How satisfied have you been, } \\
\text { on the whole, with your teeth } \\
\text { in the last three months? }\end{array}$ & $\begin{array}{l}\text { Various, depending } \\
\text { on question format }\end{array}$ \\
\hline $\begin{array}{l}\text { Oral Health- } \\
\text { Related Quality } \\
\text { of Life } \\
(\text { OHRQoL) })^{29}\end{array}$ & $\begin{array}{l}\text { Daily activities, social } \\
\text { activities, conversation }\end{array}$ & 3 & $\begin{array}{l}\text { Have problems with your teeth } \\
\text { or gums affected your daily } \\
\text { activities such as work or } \\
\text { hobbies? }\end{array}$ & $\begin{array}{l}6 \text { categories: "all of } \\
\text { the time" to "none } \\
\text { of the time" }\end{array}$ \\
\hline $\begin{array}{l}\text { Oral Impacts on } \\
\text { Daily } \\
\text { Performances } \\
(\text { OIDP) }\end{array}$ & $\begin{array}{l}\text { Performance in eating, } \\
\text { speaking, oral hygiene, } \\
\text { sleeping, appearance, } \\
\text { emotion }\end{array}$ & 9 & $\begin{array}{l}\text { Four- part questions: (A) In the } \\
\text { past } 6 \text { months, have dental } \\
\text { problems caused you any } \\
\text { difficuly in eating and } \\
\text { enjoying food? } \\
\text { (B) Have you had this } \\
\text { difficulty on a regular/ } \\
\text { periodic basis or for a period } \\
\text { or spell? (C) During the last } 6 \\
\text { months, how often have you } \\
\text { had this difficulty? (D) Using a } \\
\text { scale from 0 to 5, which } \\
\text { number reflects what impact } \\
\text { the difficulty in eating and } \\
\text { enjoying food had on your } \\
\text { daily life? }\end{array}$ & $\begin{array}{l}\text { Various, depending } \\
\text { on question format }\end{array}$ \\
\hline
\end{tabular}


At individual level ${ }^{32}$ :

- Diagnosing nature and severity of disorders.

- Assessing prognosis.

- Selecting treatments that patients value.

- Evaluating outcomes of treatment.

At population level ${ }^{32}$ :

- Monitoring spatial and time trends in oral health.

- Evaluating effects of oral health policies.

- Identifying target populations.

- Allocating resources in relation to oral health needs.

Slade and Spencer have also suggested that measures of oral health status may also be used to advocate oral health, especially when attempting to secure public funds for oral health care. ${ }^{25}$ The information provided by these measures facilitates an increasing understanding of how individuals perceive oral health needs and what oral health outcomes drive them to seek health care. In a public health context, resources for oral health care are diminishing at the same time as availability of sophisticated treatment options is increasing. For instance, dental implants are now available and are used to anchor prostheses in jaw bone which can be used to replace missing teeth. They are a comparatively expensive treatment option, and demonstrating substantial improvement in oral health related quality of life, as assessed by health status measures, could justify public funding of this type of treatment. ${ }^{25}$

\section{Problems associated with OHRQoL measures}

There are a number of reasons why these measures have, as yet, not been used by workers not involved in their development. These include:

1. Selection of the instrument: Determining which measure to use is unclear, as no substantive work to compare the relative performance of the various measures across a range of clinical situations has been published. ${ }^{33}$

2. Ambiguous scoring methods: There is still confusion as to whether ordinal scales or weights are best to assess OHRQoL. At the present time, measures which use weights to allow the severity of an impact to be described are likely to be better outcome measures. Scoring methods based on ordinal scores are prone to produce skewed results, particularly when the range of possible responses is narrow. However, the contribution of weights to the performance of health status measures has been questioned. Streiner and Norman suggested that weighting of statements does not improve the performance of a measure consisting of more than forty items. ${ }^{33}$

3. Cross cultural variations: Cross cultural relevance of the consequences of dental disorders must be considered. Allison et al reported that the nature and magnitude of impacts could vary between populations with different cultural backgrounds. This can be an issue in national population surveys. ${ }^{34}$

\section{CONCLUSION}

OHRQoL is a revolutionary measure that focuses on the patient as a whole rather than teeth and oral cavity. It sensitizes the dental health professionals, health care providers, community and the policy makers towards the priorities of the patient. Hence it influences decision making at all the levels. The overall outcome is a satisfied patient, professional and the society. Integration of such measures into oral health care programs can yield promising results. However more needs to be known about the relative performance of different measures, environmental and personal factors, organization of health care set up and positive dimensions of health which can influence QoL outcomes of the oral diseases. The theme also goes well with the fact that good oral health adds life of years.

\section{REFERENCES}

1. Gift HC and Atchinson KA. Oral Health, Health and HealthRelated Quality of life. Med Care 1995; 33 Suppl 11: NS 57Ns77.

2. Sheiham A. Oral health, general health and quality of life. Bulletin of the World Health Organisation 2005; 83(9): 641720.

3. Gift HC and Redford M. Oral health and the quality of life. Clin Geriatr Med 1992; 8(3): 673.

4. Muldoon MF, Barger SD, Flory JD, Manuck SB. What are quality of life measurements measuring? Br Med J 1998; 316 : 542-5.

5. WHO. Study Protocol for the World Health Organization project to develop a quality of life assessment instrument (WHOQOL. Qual Life Res 1993; 2(2): 153-159.

6. World Health Organization (1946). WHO definition of Health. Preamble to the Constitution of World Health Organization as adopted by the International Health Conference, New York, 
19-22June 194; signed on 22 July 1946 by the representatives of 61 states (Official Records of the World Health Organization, no.2, p.100) and entered into force on 7 April 1948.

7. Robert W. Fogel. New findings about trends in life expectation and chronic diseases: The implications for health costs and pensions. GSB selected paper series no. 76; Chicago: University of Chicago, 1996.

8. Sischo L and Broder HL. Oral Health-related Quality of Life: What, Why, How, and Future Implications. J Dent Res 2011; 90(11): 1264- 1270 .

9. Allen P.F. Assessment of oral health related quality of life. Health and Quality of Life Outcomes 2003; 1; 40.

10. Ingelhart MR and Bagramian RA. Oral Heath Related Quality of Life. 1sted. New Delhi: Quintessence Publishing Co; 2002.

11. Locker $\mathrm{D}$. The burden of oral disorders in a population of older adults. Community Dent Health 1992; 9(2): 109- 124.

12. Locker D and Slade GD. Association between clinical and subjective indicators of oral health status in an older adult population. J Gerodontol 1994; 11(2): 108-114.

13. Naito M, Yuasa H, Nomura Y, Nakayama T, Hamajima $N$ and Hananda N. Oral health status and health- related quality of life: a systematic review. J Oral Sci 2006; 48(1): 1-7.

14. WHO. Continous improvement of oral health in the $21 \mathrm{st}$ century- the approach of WHO Global Oral Health Programme. The World Oral Health Report 2003. Geneva, Switzerland: World Health Organisation.

15. Reisine ST, Fertig J, Weber J and Leder S. Impact of dental conditions on patient's quality of life. Community Dent Oral Epidemiol 1989; 17: 7-10.

16. Gift H, Reisine S and Larach D. The social impact of dental problems and visits. Am J Public Health 1989; 82: 1163- 68.

17. World Health Organisation. International classification of impairments, disability and handicaps. Geneva: World Health Organisation; 1980. www.SF-36.org

18. http://www/sf-36.org/ (accessed on 1/09/13)

19. http://www.euroqol.org/eq-5d-products/eq-5d-31.html. (accessed on 1/09/13)

20. Sunder Lal, Adarsh and Pankaj. Application of social and behavioural sciences in Health and Diseases. In: Textbook of Community medicine. 3rd revised ed. CBS Publishers: New Delhi. 2011;29-58.
21. Cushing AM, Sheiham A, Maizels J. Developing sociodental indicators: The social impact of dental disease. Community Dent Health 1986; 3: 3-17.

22. Dolan TA, Gooch BF. Associations of self reported dental health and general health measures in the Rand Health Insurance Experiment. Community Dent Oral Epidemiol 1991; 19: 1-8.

23. Atchison KA, Dolan TA. Development of the Geriatric Oral Health Assessment Index. J Dent Edu 1990; 54: 680- 687.

24. Straus RP, Hunt RJ. Understanding the value of teeth to older adults: Influences on quality of life. J Am Dent Assoc 1993; 124: $105-110$.

25. Slade GD, Spencer AJ. Development and evaluation of the oral health impact profile. Community Dent Health 1994;11: 3-11.

26. Locker D, Miller Y. Evaluation of subjective oral health status indicators. J Public Health Dent 1994; 54: 167- 176.

27. Cornell JE, Saunders MJ, Paunovich ED, Frisch MD. Effects on well being and quality of life. In: Slade GD editor. Measuring Oral Health and Quality of Life. Chapel Hill: University of North Carolina- Dental Ecology; 1997.pp 135150.

28. Leao AT, Sheiham A. The development of a sociodental measure of dental impacts on daily living. Community Dent Health 1996; 13: 22- 26.

29. Kressin N, Spiro A, Bosse R, Garcia R, Kazis L. Assessing oral health- related quality of life: Findings from the Normative Aging Study. Med Care 1996; 34: 416- 427.

30. Adulyanon S, Vourapukjaru J, Sheiham A. Oral impacts affecting daily performance in a low dental diseae Thai population. Community Dent Oral Epidemiol 1996; 24: 385 389.

31. Bowling A. Measuring disease: a review of disease - specific quality of life measurement scales. 2nd ed. Buckingham: Open University press; 2001.

32. Ebrahim S. Clinical and public health perspectives and applications of health-related quality of life measurement. Soc Sci Med 1995; 41(10): 1383-1394

33. Streiner G and Norman G. Health measurement scales: a practical guide to their development and use. Oxford: Open University Press; 1989.

34. Allison PJ, Locker D, Jokovic A and Slade G. A cross cultural study of Oral Health Values. J Dent Res 1999; 78: 643- 649. 